\title{
THE IMPACT OF INFORMATION TECHNOLOGY IN DECISION MAKING PROCESS OF COMPANIES IN KOSOVO
}

\section{UTJECAJ INFORMACIJSKE TEHNOLOGIJE U PROCESU DONOŠENJA ODLUKA U PODUZEĆIMA NA KOSOVU}

\author{
Emin Qerim Neziraj, Aferdita Berisha Shaqiri \\ Economic Faculty, University of Pristina, Pristina, Kosovo \\ Ekonomski fakultet, Sveučilište u Prištini, Priština, Kosovo
}

\begin{abstract}
Before the decision makers set much higher requirements in the decision-making than ever before due to the environment of decision-makers subject to change under the influence of progress and development of new technologies, networking individual or organization inside and the outside environment, and modern means of communication enabling continuous inflow, flow and sharing of data and information. In these modern conditions the process of collecting, analyzing, selecting data and information to make informed decisions in the context of possible restrictions and the available options, and ultimately making decisions as the basis for future business or behavior, is not simplified. The use of new technologies in the decision-making process provided numerous opportunities to facilitate decisions selection. However, the decision maker should still be able to differentiate which knowledge should be used to serve in decision making, and which models, methods, tools, systems and procedures to be used in certain situations, with the purpose of successful decision selection. In this paper, we will examine the decision making process during the business process in the companies in Kosovo.
\end{abstract}

\section{INTRODUCTION}

Every day, both personally and on business, there is a need for a choice among possible solutions by making simple or complex decisions. The selection results may have a short term impact, but can also be long-term and far-reaching nature, depending on whether the decision were successful-

\section{Sažetak}

Donositelji odluka postavljaju mnogo veće zahtjeve $u$ donošenju odluka nego ikada prije zbog okoline donositelja odluka podložnih promjenama pod utjecajem napretka i razvoja novih tehnologija, umrežavanja pojedinca ili organizacije, unutarnjeg i vanjskog okruženja te modernih sredstava komunikacije koja omogućuju kontinuirani ulaz, protok i razmjenu podataka i informacija. U tim suvremenim uvjetima nije pojednostavljen proces prikupljanja, analize, odabira podataka i informacija radi donošenja informiranih odluka u kontekstu mogućih ograničenja i raspoloživih opcija te konačno donošenja odluka kao osnova za buduće poslovanje ili ponašanje. Korištenje novih tehnologija u procesu donošenja odluka pružilo je brojne mogućnosti olakšavanja odabira odluka. Međutim, donositelj odluka i dalje moraju moći razlikovati koja znanja treba koristiti za donošenje odluka i koje modele, metode, alate, sustave i postupke koji će se koristiti u određenim situacijama, s ciljem uspješnog odabira odluka. U ovom radu ćemo ispitati proces donošenja odluka tijekom poslovnog procesa u tvrtkama na Kosovu.

ly or unsuccessfully made in an appropriate time. The decision making process involves several interrelated steps, a choice among the available options is an essential part of the process that precedes forecasting solutions to the problem and the results of the final selection. Considering that decision selection affects the success, failure and 
the outcome of a future state, it's expected from a decision-maker to solve the problem for which steps were taken previously in the decision making process. With the arrival of the market economy on the premises of the countries of Southeast Europe respectiba; as a Kosovo and increasing presence of foreign capital behind has brought new ways of management or decision-making. Also, the educational process, especially universities, in their curricula in the field of economics and management pay special attention to quality business decision-making and development management skills. Quality business decision-making is critical for business success of the company $/ \mathbf{1} /$. Decisions may be different; from those that are repetitive and simple with the easy ability to change the outcome, to decisions where careful evaluation placing increasing demands for detailed judgment and analysis is more important. If the outcome of decisions made doesn't cause greater harm, or change, the decision is less important. However, if the outcome of the decision significantly affects the individual, group of people, organization, institution or environment it is necessary to carefully reflect the steps in the decision and in the decision-making process. The purpose of decision making is to achieve a positive outcome with successful, cost-effective and timely decisions, and if possible to avoid the wrong selection of negative outcomes and to reduce or mitigate the consequences.

Problems that the decision maker faces are not always simple or uniform. The environment is largely dominated by uncertainty and risk situations, allowing the decision-making process to be more difficult, complex and demanding. The area is subject to frequent changes under the influence of new technologies and networking; modernization models, methods, tools and techniques in decision making; exchange of information and data to new forms of communication; availability of raw information and data; opportunities that are available to decision maker and so on. According to a forecast of changes, the decision-maker must be prepared to face the challenges and new trends and respond in a timely manner in order to achieve a positive outcome of the decision $/ \mathbf{2} /$. The main objectivity of this paper is: The level of information systems which used from business during decision making in Kosovo firms. Other objectives of paper is: The level of operative performance during using the IT and The level of influence decision making into operative performance /3/.

\section{LITERATURE REVIEW}

\subsection{Decision making and scientific thought}

Problems related to the decision theorists and practitioners of economic science and profession, as well as other science, deal with for many years. Interdisciplinary economy allows the decisionmaking process model application, methods, tools, systems and processes from other fields, in order to get to the important insights that will serve as a pad for making the most appropriate decisions in relation to the limited possibilities of disposing of the information and limited choices; Having regard to the dubious, uncertain and / or risk situations under whose influence decisionmaking and taking into account influences from the environment. The progress of science in many advocates would leave impact in the opinion of the decision-making process with visible common features in the approach to the issue $/ 2 /$. On the other hand, the progress of engineering and technology will greatly affect the change of approach in deciding the application of modern design methods, tools, techniques and systems with the use of existing knowledge and experience in the theory and practice. Further to technological progress and in the future contribute to the development of new approaches to decision-making and to facilitate and accelerate access to making personal and business decisions $/ 4 /$.

In recent years, many authors have their works dedicated to the study and research of decision making, which will be reflected in the decade behind us. Regarding the study and research of decision making from that period /5/. Dynamics decision-making process, considering that, regardless of the level of decision making, speed of decision-making is often a significant factor in decision-making, and current information real time serves as a support to the decision making process. Furthermore, there is an emphasis on the validity of the quality of data and information that will serve as a basis for decision making. The author proceeds to narrate the quality of decisions made in general, especially those of business, largely depends on the quality of data or information on which decisions are made, but also the rules according to which they were intended. Following the above, the author believes that the value of a particular data is determined by the 
value of the information content of the data from the perspective of decision makers, the extent to which decision-makers share certain information and data values from the standpoint of competition $/ \mathbf{6} /$. The aforementioned values can be affected by the reduction of the degree of data integrity, eliminating uncertainty in making decisions, assessing the effects of the possibilities of alternative decisions and ultimately affect the end result of selected decisions /7/. The problem of decision making has been approached to determining the optimal direction under those restrictions and the limited capacity of proposing the use of mathematical and quantitative methods to minimize wrong decisions made, and operations research seeks to solve the problem of decision-making in an uncertain and risk situation /8/. The author further states that in the course of time decision often have to be made that rely on each other where the code information with comprehensive predictive planned decision that the series has the highest priority, but for the sake of an uncertain future can be more depending on the circumstances in the environment which results in making different decisions /9/. Previously mentioned theory and practice can be applied to decisionmaking in modern conditions by using new technological solutions and systems and the networking users. Daily demand for choices among the possible solutions which the decision-maker has at his disposal vary simple short-term decisions of those more complex and the results can be longterm and of far-reaching nature, depending on whether the decision but successful or unsuccessful taken at a given moment. In order to avoid the possible errors, decisions should be based on knowledge, experience, intuition, goals, diligence, and the more information to encourage better decisions that will bring better results. If the decision maker is in front of the choices under the influence of uncertain and risky situations, decision-making process is much more difficult with potentially facing the wrong decision selection, the consequences of choices and repeated decision-making. The risk believing that it underwriting is one of the key factors in individual and business success. If possible solutions known in advance and the results of certain decisions, decision-making is not an easy process because without the person who makes decisions, decisions will never be made. Decision making weight, short-term and long-term consequences of selected decisions and responsibility for wrong deci- sions made in private and business relationships reinforce restraint in decision-making. It is always easier to bring a decision in a matter of a few days or months, when the time comes $/ \mathbf{1 0 / . ~ O n ~ t h e ~ o t h - ~}$ er hand, /10/ in article "Make better decisions" emphasizes the importance of knowledge in which case a certain way of making decisions is not applicable, and believes that the analyst is not suitable for situations where decisions must be made soon. The author believes that nearly all quantitative models, even those for predicting, are based on previously collected data, so that, if experience or intuition suggests that the past is not a good guide to present or future, should use other methods of decision-making or at least hand reach new data or analysis /11/. Following the above, the successful decision maker must distinguish which knowledge to use in certain situations when making decisions in order to avoid possible wrong decision selection. That is why, in the decision-making process and in decisionmaking quality, relevant information is required as a result of treatment and can be used in making quality decisions of any kind.

\subsection{Business decision making supported by BIS}

The use of new technologies in business activities is an indispensable part of modern management, decision-making and operations. As a support to business decision making the application of computer systems for the purpose of choosing simpler solutions in decision-making processes have long been there, increasing efficiency in the decision selection and reduce the costs of the organization. Basic features more closely explain the role of business information systems in the organization /12/. Although the computer industry has transformed the way of business transactions and data, managers were often frustrated with the attempts to use computers and information technology as a support in making decisions /9/. Recently, under the influence of technological development managers became enthusiastic about the installation of innovative projects in support for decisionmaking. However, business information systems provide decision support based on accurate, new, proven and appropriate business information, so it is necessary to adjust the same activity which deals with the organization and the objectives to be achieved for easy coverage and use of data in decision making /13/. In various decisions such as strategic decisions, operational decisions and decisions on sources of availability of communica- 
tions networks, allows access to a large amount of information and their use at low cost using databases and documents, archived knowledge, embedded models and procedures to display the requested information. Changing trends systems continue to develop and upgrade. Today, the goal is to develop a system that will allow monitoring of business enterprise by taking corrective action to improve business and making management decisions /14/.

The decision maker, if he wants to achieve optimum results in decision-making and operations, by achieving set tasks, must take into account the use of new technologies and business information systems in business decision-making, an essential part of the business, taking into account modern market trends of progress and development of new technology and the use and upgrade them in everyday business processes.

The role of business information systems in business decision making is organized to support the business data processing, office automation, management, decision-making and reporting. The impact on the business environment, business quality, fertility and effectiveness, creating new value and competitive advantage. As the role of business information systems in business decision-making is not negligible, but on the other hand, the role of new technologies in the decisionmaking process is also not negligible, it is necessary to emphasize the positive effects arising from it $/ \mathbf{1 5} /$ :

- New technological changes enable the development and emergence of new tools, models, methods, techniques and systems tailored to the requirements of decision-makers and the types of decisions,

- Increasing success in decision making,

- A greater likelihood of achieving positive outcomes of decision-making,

- The ability to use stored data and information,

- Easier access to reports,

- The possibility of feedback from decisionmakers,

- Research the possible consequences of the available decisions.

Given that, as a decision making support, uses new technology, and if necessary, the network access, we also must take into account the possible IT risks resulting from the intensive use of business information systems and technologies as important support to improve their business pro- cesses and business in general /16/. These risks are related to the dangers and threats that intensive use of business information systems may result in unintended and unexpected consequences and possible financial and other damage within the organization as well as its immediate and wider environment. On the other hand, if the application of new technologies is related to private decision making, IT risks must be taken into account because, due to the application of new technologies of network access, these are also present in the decision-making process $/ \mathbf{1 6} /$.

\subsection{Decision formation based on goals and the level of management}

Various proposals are given for the division of the decision making process on stage, but, basically, all proposals can be subsumed under the division into two basic phases, which include the preparation of decision-making and decision-making. There are four basic steps in solving business problems /17/.

- Observation needs

- The formulation of alternatives

- Assessment of alternatives

- The selection of one alternative

In the first step, which is called the informational phase, spotting the need for decision making is done. The next step is performed to define the possible alternative courses of action, and solutions. In the third phase measuring the contribution of certain alternative is done and, on that basis, the assessment of alternatives /18/. In the fourth step, based on the results of the assessment, selects one from a set of alternatives considered, which will be applied. Other, much more detailed division proposes the following phases of the process of decision-making /17/:

- Issue Tracking

- Problem ranking

- Defining the problem

- The collection of facts

- Predicting the future

- The formation model

- Troubleshooting

- Evaluation of results

- Decisions

- Execution control

- Analysis of the result of the execution 
In solving specific problems, it is necessary to specifically clarify whether the underlying problem will be solved by empirical, intuitive way or with the help of quantitative methods, because the second way requires to solve the proper procedure $/ 2 /$. Every day we make decisions without being fully aware of the situation in which we do it. Sometimes decisions are bringing automatically, without taking into account what consequences will follow its implementation $/ \mathbf{1 9} /$. That decision-makers should not fear the results of their implementation, it is necessary to consider all the available real data, process them from the standpoint of science and engineering, to evaluate and select the best possible solution at the given time that will result in a quality decision as the basis for achieving the planned target $/ \mathbf{2 0} /$. Whenever possible it is necessary to include more participants in the decision-making process, taking into account the limited time available and the urgency of that request. Nowadays, the modern managers require maximum quality, effective and operational decision making /15/. Business decision-making is a continuous activity in the company, which determines the direction and intensity of the current and future trends, and makes a series of interconnected activities. The complexity of the decision-making process is conditioned by the complexity of general business conditions. It intensifies and complicates the procedures for collecting "production" and use information; and linking them with the knowledge (through building models that are more complex) /21/. This situation requires computer support in almost all phases of the decision-making process, from preparation to control the implementation of decisions. The meaning of computer technology is the replacement of subjective assessment algorithms and decision rules $/ \mathbf{1 5} /$. In this way the formalization of methods, techniques, skills and knowledge necessary for solving problems is enabled and their installation in the software. The computer has become an integral and essential element of the process of business decision making. Further penetration of information technology in the decision-making process is to support computers in the design and use of model-making. The role of computers in this level is reflected in the achievement of the interactive dialogue on a relation user-system and this contributes to performance of problem-solving and decision-making process more efficient $/ \mathbf{9} /$.
The most important advantage is the support of computers in solving semi-structured problems. At this level, the computer system should enable easy access to relevant data and information, as well as interactive test version, so that the computer does not replace a man in the rendering of decisions, but improves the decision making process $/ 22 /$. The construction and use of modelmaking, established through a computer software package and usually upgraded on an information control system, puts the computer in the role of a generator-making, based on inputs and built-in models of decision making /23/. In this way, the computer supports the phase of objective linking, constraints and generation variants. Installation of decision making is possible and at the stage of identifying the situation (diagnosis), and the control phase of implementation of the decision /9/. In this way, most of the activities of the business decision-making process are supported by the computer. The actual selection is conducted by a man. The basis of information systems are still relational databases, and are increasingly used object and multidimensional database. The development of information technologies has enabled the emergence of the computer as the proponent of the decision $/ \mathbf{9 /}$. The computer receives a personal "intelligence", knowledge and manner of use of this knowledge so it can do the decisionmaking process. All phases of the decisionmaking process, including the selection phase, are carried out using a computer (software packages) /24/. So, at this level, computer (on the basis of a computer program, information and knowledge) has the role of proponents of the decision, which one can accept or not accept /25/. These shims are called systems for decision support and expert systems /26/.

\section{METHODOLOGY}

The research methods that we used in this paper are methods which using in the social science, because the issue as decision making, information using is social categories, according to this social method of research also the results explanation will be provide with adequate method. In this research was use the quantitative, method with deductive approach, so we want to exist theory of decision making and information to confirm with analyses part regarding with quantitative data /27/: Before application the mention method and scientific approach it is important to explain the how the use and which sources was used for this 
paper. First of all, the $t$ main secondary sources of information include foreign and domestic literature: books, scientific journals, and the Internet. The primary sources of information are based on the two part of questionaries' of PhD thesis with title The influences of Business intelligence on decision making which include the part of process decision making in the Kosova Enterprises and the using level of information systems by them.

\subsection{Research sample}

According to statistical report form ASAK2016 we can conclude that the number of medium and big manufacturing enterprises in the Republic of Kosovo is 60 , so for this study the selected samples is 54 (fifty-four) enterprises, of which 46 (forty-six ) are medium and 8 (eight) large or biggest, accorded with a $95 \%$ accuracy of 0.05 . So based on the enterprise sample we have selected 1337 respondents or 1337 managers of all levels. The next table will be present the respondent's opinion according to the statistical variability regarding with case of report between level of managers and making strategic decision.

\subsection{Operationalization of variables}

For instance, to explain and know which is level of using the information systems in Kosova enter- prises during in decision making process in this paper will be present and using the variables such is: Decision quality, Performance and level of using information systems. The variable decision quality is depended variables, performance and level of using information systems are independent variables. The testing model will have based on factor regression equation.



The main equation was used on testing the hypotheses in this paper which is:

H1: The lack of integration of information systems in enterprises affects the quality of decisionmaking

$\mathrm{H} 2$ : The performance influence in the decision quality

H3: The information system may influence in the decision quality

\section{ANALYSES OF CASE STUDIES}

As we can see in the table 1, low managers make strategic decisions - little since, the their average is 1.27 and the data distribution is 1546 with its coefficient of $20.59 \%$, which means that the average is acceptable and reliable.

Table 1: The average and statistical variability of the ratio between the level of managers in the enterprise and the making of strategic decisions by them



While middle managers make strategic decisions at a satisfactory level, their average is 2.86 , with variance 1532 , with a $10.25 \%$ coefficient. As for senior managers, the results show that they make strategic decisions at a satisfactory level, as the average of their responses is 2.85 with the variance 1555 and the coefficient $0.08 \%$. The theory of decision making says and instructs that only top managers make strategic decisions /28/ and other levels of management made just participation on decision making, our research shows that in enterprises of Kosovo, besides top managers, strategic decisions also receive lower and middle managers, but at a lower level, which directly affects the ineffective and inefficient management of enterprises in Kosovo.

In the Table 2 we will present data on ways of making decisions of Kosovar managers. Out of 
three forms of decision-making measured by the values of statistical variability measures, intuitive decisions, knowledge-based decisions, and decisions based on analysis or rational decisions. Fol- lowing will be a table with results that show how the managers of the respective levels make decisions based on the intuition.

Table 2. Average and statistical variability of the relationship between the level of managers in the enterprise and decision-making based on their intuition

\begin{tabular}{|c|c|c|c|c|c|}
\hline \multirow{2}{*}{$\begin{array}{c}\text { Managers } \\
\text { Level }\end{array}$} & \multicolumn{5}{|c|}{ Intuitive decision } \\
\hline & Total & $\mathrm{Me}$ & Variance & Sdev & Coefficient \\
\hline $\begin{array}{c}\text { The mid- } \\
\text { dle man- } \\
\text { agers }\end{array}$ & 382 & 2,01 & 1539,856 & 24,4 & $8,23 \%$ \\
\hline $\begin{array}{l}\text { The Low } \\
\text { managers }\end{array}$ & \multirow[t]{2}{*}{764} & 1,75 & 2339,750 & 28,45 & $6,15 \%$ \\
\hline $\begin{array}{l}\text { Top Man- } \\
\text { agers }\end{array}$ & & 2,64 & 1338,3218 & 20,28 & $13,05 \%$ \\
\hline Total & 1137 & & & & \\
\hline
\end{tabular}

In table 3 the results show that the Low managers are based on little intuition while making decisions (more generally - see table no in the appendix), with average 1.75 and variance 2339 , with a coefficient of $6.15 \%$. Medium managers rely little on intuition when making decisions (more generally - see table no in the appendix of this paper), average 2.01 and variance 1539 , with $8.23 \%$ coeffi- cient. Top managers are based on a sufficient level of intuition when making decisions (more generally - see table no in the appendix of this paper), average 2.01 and variance 1539 , with a coefficient of $13.05 \%$. In the following table we will present the relationship between management position and support systems during decision making.

Table 3. Relationship between Managerial Position and Support Systems in MBE in Kosovo

\begin{tabular}{|c|c|c|c|c|c|}
\hline \multicolumn{2}{|c|}{ Managers Level } & No & Sometimes & Yes & Total \\
\hline $\begin{array}{l}\text { The middle } \\
\text { managers }\end{array}$ & $\begin{array}{l}\% \\
\% \text { of } \\
\text { Total }\end{array}$ & $\begin{array}{r}20,0 \% \\
5,3 \%\end{array}$ & $\begin{array}{r}20,0 \% \\
5,3 \%\end{array}$ & $\begin{array}{l}60,0 \% \\
15,8 \%\end{array}$ & $\begin{array}{r}100,0 \% \\
26,3 \%\end{array}$ \\
\hline $\begin{array}{l}\text { The low } \\
\text { level of } \\
\text { managers }\end{array}$ & $\begin{array}{l}\% \\
\% \text { of } \\
\text { Total }\end{array}$ & $\begin{array}{l}0,0 \% \\
0,0 \%\end{array}$ & $\begin{array}{r}100,0 \% \\
5,3 \%\end{array}$ & $\begin{array}{l}0,0 \% \\
0,0 \%\end{array}$ & $\begin{array}{r}100,0 \% \\
5,3 \%\end{array}$ \\
\hline $\begin{array}{l}\text { The top } \\
\text { managers }\end{array}$ & $\begin{array}{l}\% \\
\% \text { of } \\
\text { Total }\end{array}$ & $\begin{array}{l}16,7 \% \\
10,5 \%\end{array}$ & $\begin{array}{l}50,0 \% \\
31,6 \%\end{array}$ & $\begin{array}{l}33,3 \% \\
21,1 \%\end{array}$ & $\begin{array}{r}100,0 \% \\
63,2 \%\end{array}$ \\
\hline & $\begin{array}{l}\% \\
\% \text { of } \\
\text { Total }\end{array}$ & $\begin{array}{l}15,8 \% \\
15,8 \%\end{array}$ & $\begin{array}{l}42,1 \% \\
42,1 \%\end{array}$ & $\begin{array}{l}36,8 \% \\
36,8 \%\end{array}$ & $\begin{array}{l}100,0 \% \\
100,0 \%\end{array}$ \\
\hline
\end{tabular}

Based on the results from table no. we can conclude that: The $100 \%$ or 764 of low-level managers sometimes use support systems (SS-s) during decision-making, Secondary managers $20 \%$ of them, or expressed in number, 76 of them do not use SS during decision making, $60 \%$ of them, or, expressed in numbers 230 use SS during decision making and $20 \%$ of them, or, expressed With number of, 76 of them sometimes use SS decisionmaking. From this we can conclude that $80 \%$, or, 296 of middle managers use SM during decisionmaking While $16.7 \%$, or, expressed in numbers, 32 senior managers do not use SS during decisionmaking, $33.3 \%$, or, 64 senior managers use SS 
every time, $50 \%$, or, 155 senior managers use SS.

between variables regarding with their categories

Following figure 1 present the factor analyses

Figure 1. The Scree Plot of factor analyses for the variables
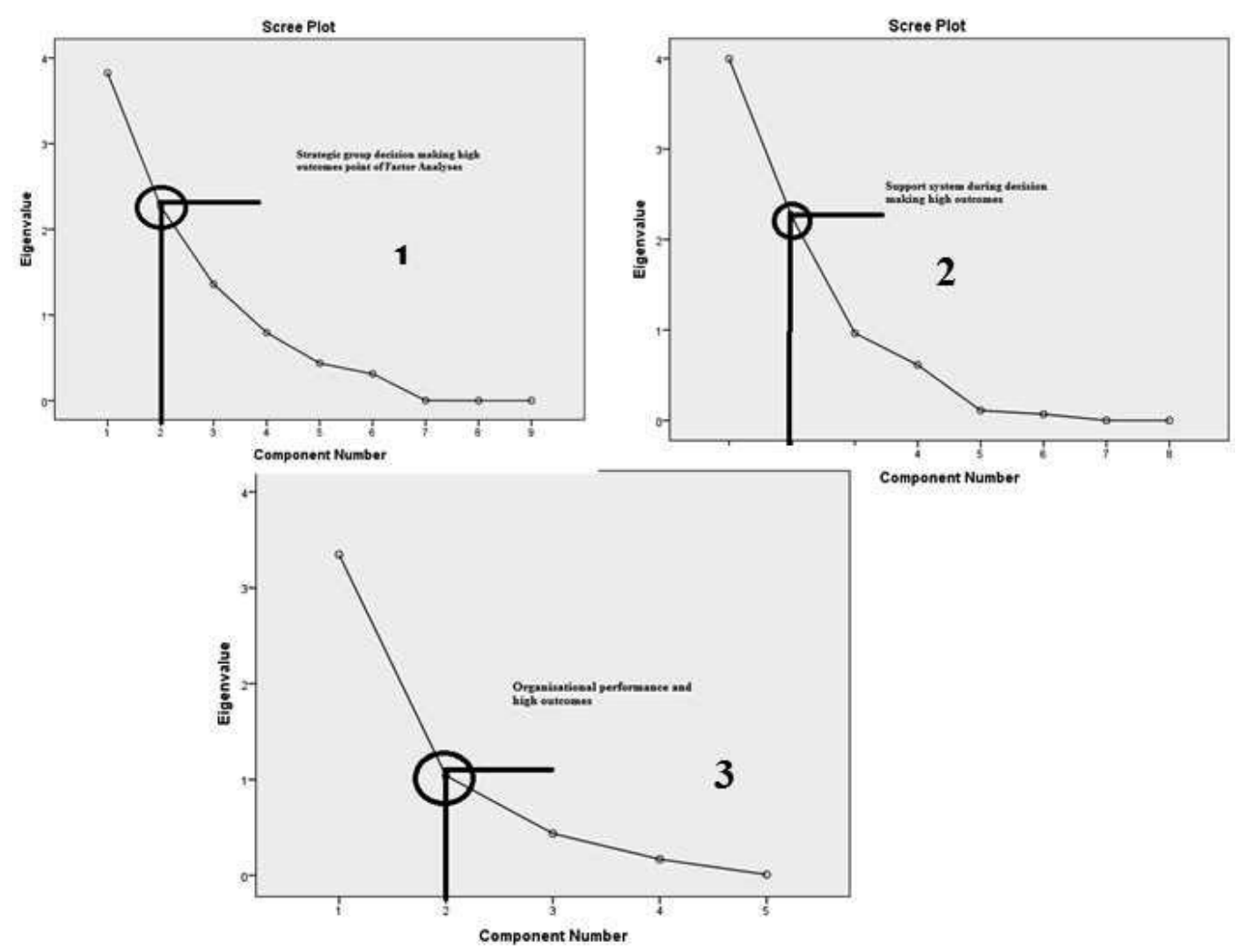

As we can see the derivate of factor analyses in this study is variabiles strategic group decision making, supporting systems and organiyational performance

Table 5 will present the correlation between variabiles strategic group decision making, support- ing systems during decision making and organizational performance. As far as theoretical support exists There are some definitions by different authors regarding the meaning of the correlation analysis, but all those definitions have almost the same meaning. Correlation analysis is a measure of inter link ability between the two variables.

Table 4 Correlations between variabiles

\begin{tabular}{|c|c|c|c|c|}
\hline & & $\begin{array}{c}\text { Strategic group } \\
\text { decision }\end{array}$ & $\begin{array}{c}\text { Support sys- } \\
\text { tems during } \\
\text { decision making }\end{array}$ & $\begin{array}{l}\text { Organizational } \\
\text { performance }\end{array}$ \\
\hline \multirow{4}{*}{ Pearson Correlation } & Strategic gour decision & 1,000 & 899 & ,951 \\
\hline & $\begin{array}{l}\text { Support systems during } \\
\text { decision making }\end{array}$ & 899, & 1,000 & ,984 \\
\hline & Organizational performance & ,951 & ,984 & 1,000 \\
\hline & Strategic gour decision & & 003 & 000 \\
\hline \multirow[t]{3}{*}{ Sig. (1-tailed) } & $\begin{array}{l}\text { Support systems during } \\
\text { decision making }\end{array}$ & 003, & & , 000 \\
\hline & Organizational performance & , 000 & 000 & \\
\hline & Strategic gour decision & 1337 & 1337 & 1337 \\
\hline \multirow[t]{2}{*}{$\mathrm{N}$} & $\begin{array}{l}\text { Support systems during } \\
\text { decision making }\end{array}$ & 1337 & 1337 & 1337 \\
\hline & Organizational performance & 1337 & 1337 & 1337 \\
\hline
\end{tabular}


The correlation analyses show us the possitive correlation between variabiles with the high results ,951, 984,899 and signifikance ,000 and ,003. The meaning of this possitive relation is that the testing model inside has the relative variabiles which influence between each other. The table no present the $\mathrm{R}$ value of testing regresion equtioan model.

Table 5 Model Summaryb

\begin{tabular}{|l|r|r|r|c|}
\hline Model & \multicolumn{1}{|c|}{$\mathrm{R}$} & R Square & \multicolumn{1}{|c|}{$\begin{array}{c}\text { Adjusted R } \\
\text { Square }\end{array}$} & $\begin{array}{c}\text { Std. Error of the } \\
\text { Estimate }\end{array}$ \\
\hline 1 &, $972^{\mathrm{a}}$ &, 945 &, 918 &, 30339829 \\
\hline
\end{tabular}

a. Predictors: (Constant), Organizational performance, Support ys-

tems during decision making

b. Dependent Variable: Strategic group decision

The table 6 model summary present that the Adjusted R Square is very high ,918 that mean the support information systems both with operative performance indicate to quality decision and there are in depentdent correlation. On the other way of view we can conclude that predictor variabiles organizational perfomance and support systems influence on strategic groupdecision. The next table 7 will present dhe regresion and resudual value of ANOVA model.

Table 6 ANOVA Reusults ${ }^{a}$

\begin{tabular}{|rl|r|r|r|r|r|}
\hline Model & & Sum of Squares & df & Mean Square & F & Sig. \\
\hline \multirow{2}{*}{1} & Regression & 6,358 & 2 & 3,179 & 34,538 &, $003^{\mathrm{b}}$ \\
& Residual &, 368 & 4 &, 092 & & \\
& Total & 6,727 & 6 & & & \\
\hline
\end{tabular}

a. Dependent Variable: Strategic gruop decision

b. Predictors: (Constant), Organizational performance, Support systems during decision making

So the significance of regression model is 0,003 that mean the performance and information system influence on decision making strategic pro- cess if we see the Hypotheses we can conclude that the $\mathrm{H} 2$ and $\mathrm{H} 3$ are approve. The model value of $\mathrm{B}$ coefficient can be seen in the table 8 .

Table 7 Coefficients ${ }^{\mathrm{a}}$

\begin{tabular}{|c|c|c|c|c|c|c|}
\hline \multirow{2}{*}{\multicolumn{2}{|c|}{ Model }} & \multicolumn{2}{|c|}{ Unstandardized Coefficients } & \multirow{2}{*}{$\begin{array}{c}\begin{array}{c}\text { Standardized } \\
\text { Coefficients }\end{array} \\
\text { Beta }\end{array}$} & \multirow[t]{2}{*}{$\mathrm{t}$} & \multirow[t]{2}{*}{ Sig. } \\
\hline & & B & Std. Error & & & \\
\hline \multirow{3}{*}{1} & (Constant) & 243 & ,152 & & 1,605 & , 184 \\
\hline & $\begin{array}{l}\text { Support systems during } \\
\text { decision making }\end{array}$ & 1,193 & ,690 & 1,126 & 1,728 & , 159 \\
\hline & Organizational performance & 2,204 & 698 & 2,059 & 3,159 & ,034 \\
\hline
\end{tabular}

a. Dependent Variable: Strategic group decision

So the constant variable which is strategic group decision is 243 with the significance of 0,184 the independent variable support systems during decision making have the value of beta coefficient is 1.193 with sig $=0.159$ and organizational performance 2.204 with sig 0,34 . So, those value of variables can using for the model for testing hypothesis.

The problem in companies of Kosovo according to $\mathrm{H} 1$ is No integration of information system be- tween management sectors and level and in the future the managers must work in to creation integrity in all enterprises the support system.

\section{CONCLUSION}

The decision maker, when deciding, faces unambiguous, dubious and risky situations, fear of decision-making and other restrictions that can make decision-making process difficult slow it down or disable it /31/. For the quality decisionmaking in such circumstances a timely dispose of 
information is necessary, carrying out an assessment of potential solutions and analysis of the impact of the environment with a view to a positive outcome. Since every decision brings changes, timely decision selection among possible solutions will be reflected in the short term or the long term on the further course of actions of decision makers in relation to the outcomes. Companies from the countries of Kosovo are increasingly applying the concept of business decision-making because they themselves have realized the necessity of timely business activity. For this purpose, various business information systems that facilitate the decision-making process and thus profitable fixes are used. Investment in such systems should be seen as a cost-effective investment, although these systems are expensive. Separation of important from less important data and information and the ability of timely and accurate decision-making differs the unsuccessful from successful decision makers. Therefore, the decision maker must be aware of new technologies and modern trends and be ready to face the challenges of today. The original role of computer systems is the collection, processing, storage and availability of data and information for future use and sharing. Data and information needed to determine the possibilities of available decision are available to the decision maker by simplifying choice by converting them into new opportunities, knowledge, future development opportunities among new values. Since the decision maker makes the final decision, the new technology also plays an important role in the process of private and business decision-making by providing assistance in calculating a greater choice of possible solutions. By analyzing the problems and consequences of the selection, the forecast of future selection results, reducing fear in decisionmaking, simplification in the selection decision, the new capabilities in the mode of thinking and choosing solutions, creating new value. The role of new technologies in the private and business decision-making is repeated.

As the new technologies primarily affect the development and emergence of new tools, models, methods, techniques and systems that are tailored to customer requirements, and decision makers, but also the types of decisions that need to be made, there is a requirement that the upgrade and use are continued in the future in order to improve and simplify the decision-making process.
Furthermore, increasing success in decision making, achieving a positive outcome of decisionmaking, use of stored data and information, easier access to reports, the possibility of feedback from decision-makers, the research potential consequences of available decision are just some of the benefits arising precisely from the use of new technology in the decision-making process.

Notes

/1/ G. A. Knight (1997), Cross-cultural Reliability and Validity of a Scale to Measure Firm Entrepreneurial Orientation, Journal of Business Venturing, 12 pg.121132

/2/ T. Babarović; I. Šverko (2012.), Teorijsko utemeljenje računalnih sustava za profesionalno savjetovanje, Društvena istraživanja, Vol. 21, No. 4 ,pg. 118-129

/3/ E. Santarelli (2006), Entrepreneurship, Growth and Innovation: The Dynamics of Firms and Industries, Springer Science+Business Media Inc., New York, pg.221-234

/4/ B. Kogut (2003.), The Global Internet Economy, Chicago: Massachusetts Institute of Technology, pg.161

/5/ A.Bard; J. Soderquist, (2002.), Netokracija - nova elita moći $i$ život poslije kapitalizma, Differo d.o.o., Zagreb, pg. 432-444

/6/ D. Barković (2004.), Operacijska istraživanja u investicijskom odlučivanju, Sveučilište J. J. Strossmayera u Osijeku, Ekonomski fakultet u Osijeku, Osijek, ISBN 935-6073-84-6. pg.356-360

/7/ J. T. Allen (1984.), Managing the Flow of Technology: Technology Transfer and the Dissemination of Technological Information, pg.112-127

/8/ S. Chen (2005.), Strategic Management of e-Business, Chichester : John Wiley \&Sons, pg.332

19/ P. Drucker (2006.), Upravljanje u budućem društvu, M.E.P. Consult, Zagreb. pg.206

/10/ T. H. Davenport (2009.), Kako do boljih odluka, Banka, MZB, Zagreb, 12 , pg.199-221

/11/ M. Castells (2009), Communication Power, Oxford University Press Inc., New York, United States, ISBN 978-0-19-956704-1.pg. 13-24

/12/ Ž. Holjevac (2012.), Važnost jednakosti pred zakonom i komunikacijske revolucije u procesu oblikovanja modernih europskih nacija, Povijest $u$ nastavi, Društvo za hrvatsku povjesnicu, Zagreb, br. 1 pg. 19-32

/13/ J. Tidd; J.Bessant; K. Pavitt (2005), Managing Innovation, Integrating Technological, Market and Organizational Change, John Wiley \& Sons Ltd. Third edition. ISBN 0-470-09326-9, pg.334-336

/14/ D.G.Severance; J. Passino (2009.), IT u primjeni, MATE d.o.o., Zagreb, pg.453-457

/15/ T.F.Gattiker; D.L. Goodhue (2002), Softwaredrivenchanges to business processes: an empirical study of impacts of Enterprise Resource Planning 
(ERP) systems at the local level, International Journal of Production Research, pg.98-105

/16/ B. Grabot; A. Mayere; I. Bazet (2008), ERP Systems and Organisational Change: A Sociotechnical Insight, London: Springer-Verlag, pg.129-141

/17/ M. Hammer; J. Champy (2001), Reinženjering tortke, Mate d.o.o., Zagreb, pg.301

/18/ S. Rebello (1991.), Long-run policy analysis and longrun growth, Journal of Political Economy , pg73-82

/19/ G.Vukši (2005.), Utjecaj izravnih stranih ulaganja na izvoz hrvatske prerađivačke industrije, Financijska teorija i praksa 29, pg. 101-114

/20/ D.G. Bhatt; F.A. Emdad (2010.), An empirical examination of the relationship between information technology (IT) infrastructure, customer focus, and business advantages. Journal of Systems and Information Technology, 12(1), pg. 212-216

/21/ S. Stern; M.E. Porter; J.L. Furman (2000.), The Determinants of National Innovative Capacity, National Bureau of Economic Research, Cambridge, Working Paper, No. 7876, pg.4-13

/22/ L.C.Bovée; V.J.Thill (2011), Suvremena poslovna komunikacija. 10. izd. Zagreb: Mate.

/23/ S.K.Sharma; J.N.D. Gupta (2003), Improving Workers' Productivity and Reducing Internet Abuse. Journal of Computer Information Systems [online], 44 (2) pg.23-34

/24/ J.G. Covin; D.P. Slevin (1989), Strategic Management of Small Firms in Hostile and Benign Environments, Strategic Management Journal, 10, pg.48-61
/25/ K.Ćurko (2001.), Skladište podataka - sustav za potporu odlučivanju, Ekonomski pregled, 52 (7. - 8.), Hrvatsko društvo ekonomista, Zagreb, pg.109-121

/26/ V.Čerić, M. Varga (2004.), Informacijska tehnologija u poslovanju, Element, Zagreb, pg.312

/27/ B. Aktan, C. Bulut (2008), Financial Performance Impacts of Corporate Entrepreneurship in Emerging Markets: A Case of Turkey, European Journal of Economics, Finance and Administrative Science, 12, pg.678689

/28/ V. Kume (2002) , Strategic Management, it's a frill or need for Albanian businesses, Economy and Business, NR. 4, pg.22-29

/29/ M. Čupić; Ž. Mihajlović ( 2010) , Computer-Based Knowledge, Self-Assessment and Training, Journal of engineering education, Volume 26 Issue 1 , Tempus Publications, ISSN 949-149X/91 Pg 111-125

/30/B.J. Taylor (2012), Models for professional judgement in social work, European Journal of Social Work, 15(4), pg 546-562.[DOI: 10.1080/13691457.2012.702310] http://www.tandfonline.com/doi/full/10.1080/13691 457.2012.702310

/31/ G. Ahuja; C.M. Lampert (2001), Entrepreneurship in the large corporation: A longitudinal study of how established companies create breakthrough inventions, Strategic Management Journal, 22, pg34-45 